\section{Is the Purchasing Behavior of Suburban Millennials Affected by Social Media Marketing? Empirical Evidence from Malaysia}

KOME - An International Journal of Pure Communication Inquiry Volume 7 Issue 2, p. 104-127. (C) The Author(s) 2019

Reprints and Permission: kome@komejournal.com

Published by the Hungarian Communication Studies Association DOI: $10.17646 /$ KOME.75672.38

\author{
Amran Harun ${ }^{1,2}$ and Wann Huzida Roza Husin ${ }^{1}$ \\ ${ }^{1}$ Faculty of Technology Management and Business, Universiti Tun Hussein Onn \\ Malaysia, MALAYSIA \\ ${ }^{2}$ Institute for Social Transformation and Regional Development (TRANSFORM), \\ Universiti Tun Hussein Onn Malaysia, MALAYSIA
}

\begin{abstract}
An abundance of social media marketing research has been conducted on urban consumers, but notably, only a few attempts have been made in understanding suburban consumers, especially on low involvement products. Due to this lack of research, this study aims to understand how social media marketing influences online purchasing behavior of Millennials in suburban areas of low involvement products. This study adapts the theory of uses and gratification to justify online purchasing behavior among Millennials. This study also seeks to understand the role of consumer engagement as a moderator. A total of 384 respondents, aged between 18-35 years old who have experience purchasing low involvement products through online websites took part in this study. The results indicated that three (3) social media marketing dimensions, namely online communities, entertainment, and perceived trust, had significant effects on the Millennials' online purchasing behavior of low involvement products. However, consumer engagement did not moderate the relationship between social media marketing dimensions and the online purchasing behavior of Millennials regarding low involvement products. This study contributes to the integration of two new dimensions, namely entertainment and perceived trust in the concept of social media marketing. The findings have supported the uses and gratification theory, whereby Millennials in suburban areas inclined to choose their favorite online websites to fulfill their needs and wants. This finding also helped marketing managers to design their websites to cater to the unique trends of Millennials. Apart from that, this study also contributes to the marketing literature in relation to the space of low involvement products, consumer engagement, and Millennials' online purchasing behavior.
\end{abstract}

Keywords: online purchasing behavior, low involvement products, Malaysian e-commerce, social media marketing, consumer engagement, uses and gratification theory 